\title{
Influence of technical and electrical equipment in life cycle assessments of buildings: case of a laboratory and research building
}

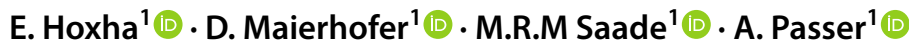

Received: 6 November 2020 / Accepted: 21 April 2021 / Published online: 12 May 2021

(c) The Author(s) 2021

\begin{abstract}
Purpose A detailed assessment of the environmental impacts of the building requires a substantial amount of data that is time- and effort-consuming. However, limitation of the system boundary to certain materials and components can provide misleading impact calculation. In order to calculate the error gap between detailed and simplified assessments, the purpose of this article is to present a detailed calculation of the environmental impacts of the building by including in the system boundary, the technical, and electrical equipment.

Method To that end, the environmental impacts of a laboratory and research building situated in Graz-Austria are assessed following the EN-15978 norm. Within the system boundaries of the study, the material and components of building fabric, technical, and electronic equipment for the building lifecycle stages of production, construction, replacement, operational energy and water, and end-of-life are considered. The input data regarding the quantity of materials is collected from the design and tendering documents, invoices, and from discussion with the head of the building's construction site. Primary energy and global warming potential indicators are calculated on the basis of a functional unit of $1 \mathrm{~m}^{2}$ of energy reference area (ERA) per year, considering a reference building service life of 50 years.

Results and discussion The primary energy indicator of the building is equal to $1698 \mathrm{MJ} / \mathrm{m}^{2}{ }_{\mathrm{ERA}} / \mathrm{year}$. The embodied impacts are found to be responsible for $28 \%$ of which $6.4 \%$ is due to technical and electronic equipment. Furthermore, the embodied impacts for the global warming potential, equal to $28.3 \mathrm{~kg} \mathrm{CO}_{2} \mathrm{e} / \mathrm{m}^{2}{ }_{\mathrm{ERA}} /$ year, are responsible for $73 \%$. Together, technical and electrical equipment are the largest responsible aspects, accounting for $38 \%$ of the total impacts. Simplified and detailed result comparisons show a gap of $29 \%$ and $7.7 \%$ for global warming and primary energy indicators. These differences were from the embodied impacts and largely from the exclusion of electrical equipment from the study's system boundary.

Conclusions Technical and electrical equipment present a significant contribution to the overall environmental impacts of the building. Worthy of inclusion in the system boundary of the study, the environmental impacts of technical and electrical equipment must be calculated in detail or considered with a reliable ratio in the early design phase of the project. Further research is necessary to address the detailed impact calculation of the equipment and notably the minimization of their impacts.
\end{abstract}

Keywords Laboratory and research building · Life cycle assessment · Detailed vs. simplified assessment · Technical and electrical equipment

\section{Introduction}

Life cycle assessments (LCA) of buildings are increasingly found in the relevant specialized literature (Buyle et al. 2013;

Communicated by Holger Wallbaum.

E. Hoxha

endrit.hoxha@tugraz.at

$\triangle$ A. Passer

alexander.passer@tugraz.at

1 Graz University of Technology, Institute of Technology and Testing of Construction Materials, Working Group Sustainable Construction, Graz, Austria
Pomponi and Moncaster 2016; Spirinckx et al. 2018). Due to the substantial amount of materials and components within a building, and due to their long service life, building LCAs requires an unsurmountable amount of data and the careful delineation of future scenarios in terms of its use and end-oflife (Passer et al. 2016; Häfliger et al. 2017; Zhang et al. 2019).

Most studies on buildings' environmental performance, until very recently, were focused on the operational energy intensity, 
aimed at diminishing what seemed to be the greatest contributor to buildings' environmental impacts (Blengini and Di Carlo 2010). However, the focus has recently begun to shift to the embodied impact, mostly related to material manufacturing and disposal (Röck et al. 2020a, b). The importance of the embodied loads of buildings has been made evident due to the increased energy efficiency of the use stage, which-in turn-led to an increase in the amount and complexity of materials consumed to provide a decrease in energy consumption. Increased thermal insulation or technical and electrical on-site equipment hold the potential to increase a building's environmental impact and should be properly investigated and accounted for. Most importantly, as governments increasingly attempt to meet the targets set within the Paris agreement, aiming to keep global warming below $1.5^{\circ} \mathrm{C}$ until 2050 (IPCC 2018), the reduction of embodied GHG emissions of new constructions is paramount, since they occur upfront (before the use of the building) and incur on a so-called "carbon spike" (Säynäjoki et al. 2012; Häkkinen et al. 2015; Röck et al. 2020a, b) that can take up a significant portion of countries' carbon budgets (Habert et al. 2020).

This increased focus on building LCAs, with a clearer perception of the importance of embodied impact, is most commonly documented on individual building LCAs (Blengini 2009; Kofoworola and Gheewala 2008; Kua and Wong 2012; Stephan et al. 2013; Sinha et al. 2016; Echarri-Iribarren et al. 2019). As shown in the extensive review published by Röck et al. (2020a, b), many studies can be found which focus on single- and multi-family dwellings and, to a slightly lesser extent, on office buildings. However, governments and universities face pressure to build low-impact and highly energyefficient public buildings (Allianz Nachhaltige Universitäten in Österreich 2020; CCCA 2020), to serve as examples and to help increase knowledge on the performance of these novel building concepts. Particularly for academic research institutes investigating environmental impacts of the built environment, one could expect that access to detailed university building plans might be easier than to office and residential, but this is not confirmed in the scientific literature. Few studies performed detailed LCAs of laboratory and research buildings when compared to residential dwellings, for instance. A very comprehensive study was developed by Scheuer et al. (2003), covering the LCA of a building located on the University of Michigan campus. The authors considered an exhaustive bill of building materials and components, covering both technical and electrical equipment, by consulting various design documents, sub-contractors, and manufacturers, and performing onsite measurements (Scheuer et al. 2003). However, the study is already 17 years old and, for that reason, fails to reflect current developments in operational energy efficiency - which significantly alter the environmental performance balance within a building. The same level of detail for the LCA of laboratory and research buildings is not easily found in the literature since the aforementioned study came out. Aside from Vuarnoz et al.
(2020) and Hoxha et al. (2020a), LCAs of university buildings are usually limited to the building fabric, namely, the structural materials, cladding, insulation, and main finishes (Wu et al. 2012; Azari 2014; Kofoworola and Gheewala 2008; Asdrubali et al. 2013; Xie et al. 2018; Wang et al. 2018; Biswas 2014; Azzouz et al. 2017; Attia 2016; Eberhardt et al. 2019), or even just to major materials consumed (Chang et al. 2019), and often not covering all life cycle stages (Varun Sharma et al. 2012; Xue et al. 2020).

When performing a whole-building LCA, the choice of system boundaries - in terms of both life cycle stages considered and of materials and components included-significantly influences the final results (Kellenberger and Althaus 2009; Pan et al. 2018; Rasmussen et al. 2019). The interdependencies between components and systems embedded in a building amount to a complex structure. This prevents it from being properly analyzed through a reductionist approach, whereby there is the assumption that the lifecycle impact is merely a sum of the life cycle impacts of its individual parts or stages.

In this study, we aim to comprehensively evaluate the life cycle environmental impacts of a laboratory and research building, showing the gap between a simplified and a detailed LCA, encompassing technical and electrical equipment, and highlighting hotspots for building components throughout all life cycle stages. We aim to prove that if laboratory and research buildings are to be built with low-carbon technologies to serve as benchmarks or references for future construction, a detailed assessment such as the one we propose must be employed.

\section{Method}

The LCA herein described was performed according to the European Standard EN-15978. (2011). The standard determines that the setting of system boundaries must follow the "modularity principle," which states that processes influencing the building's environmental performance must be assigned to the life cycle where they occur. The life cycle modules referred to are illustrated in Fig. 1, highlighting those that were considered in this study.

In the so-called "product stage," namely, modules A1 to A3, the extraction of raw materials for manufacturing all building materials and components is accounted for, along with their transportation to factories followed by the manufacturing process itself. The amounts of each material and component used in the building were gathered from the design and tendering documents provided by the designers. The varied nature of these documents required a structured approach to properly extract the building's detailed bill of quantities, by decomposing different building elements until reaching the material level. Since the goal of this assessment was to be as comprehensive as possible, no cut-off approach was applied, and all materials listed in the 
Fig. 1 Building life cycle stages according to EN-15978. (2011)
INFORMATION REGARDING THE LIFE CYCLE OF THE BUILDING
ADDITIONAL

INFO

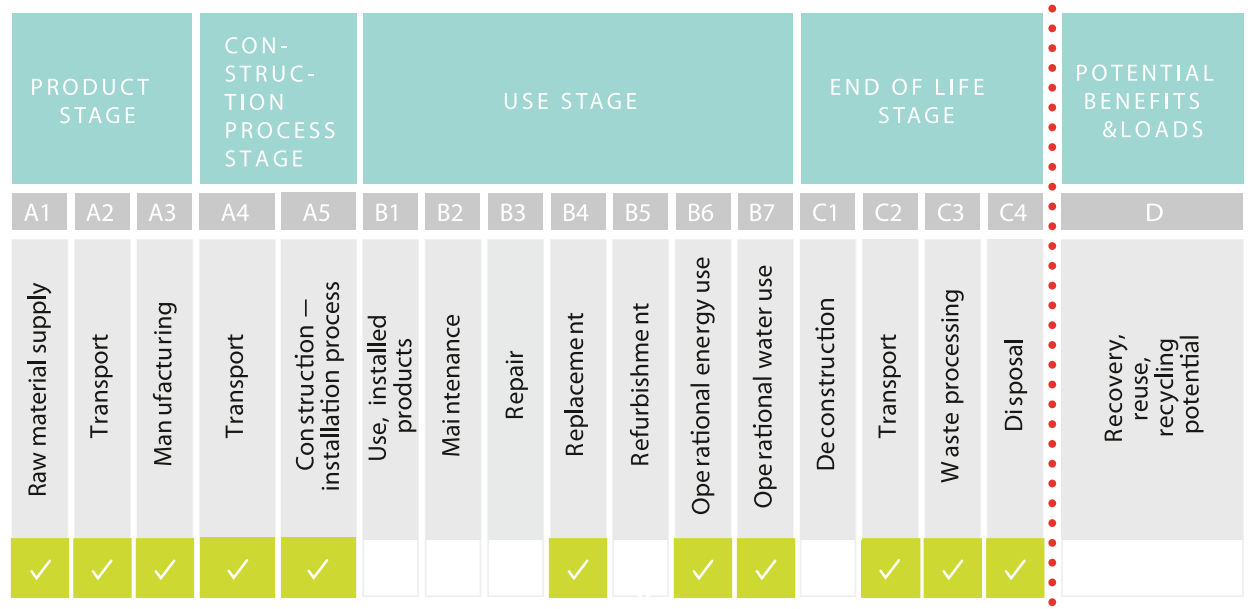

tendering documents were included in the LCA. The quantities for these modules have been obtained from the tender documents of the building. Modules A4 and A5 refer to the building's construction process, namely, the transport of materials and components to the building site, along with the actual assembly of the building. The transportation distances from factories to the site and the consumption of fuel and electricity for construction purposes were provided by the head of the building's construction site.

The use phase of the building, represented by modules B1 to B5, encompasses the predicted maintenance, repair, replacement, and refurbishment processes. We determined the replacement rates of each building component based on their expected service life (ESL). ESL for the different materials and components within the building fabric are taken from the BNB Service Life Catalog (2017), and ESL values for the technical and electrical equipment are taken from the VDI-2067 catalog (2008). The number of replacements was calculated using the EN 15978 guidelines, following Eq. 1.

$N_{R}(j)=E\left\lceil\frac{\operatorname{ReqSL}}{(\operatorname{ESL}(j))}-1\right\rceil$

where:

$E\left\lceil\frac{\operatorname{ReqSL}}{(\operatorname{ESL}(j))}-1\right\rceil$ is the function that rounds the number of replacements to the highest integer, to assure that replacements scheduled for the end of the building's service life are not accounted for:

$\operatorname{ESL}(j)$ is the estimated service life for product $j$;

$N_{R}(j)$ is the number of replacements for product $\mathrm{j}$;

ReqSL is the required service life of the building (set to 50 years in this case).
The operational energy and water use referred to in modules B6 and B7 encompasses all energy and water consumed for heating, cooling, ventilation, hot water, lighting, and appliances. The operational energy demand of the assessed building is covered by electricity and by district heating. Electricity is used for all appliances, while district heating is only triggered when necessary as an additional source when the temperature reaches values below $-7^{\circ} \mathrm{C}$. The values for the operational energy use have been obtained from the electricity demand stated in the design documents of the HVAC systems, which are calculated according to current Austrian standards. As for the operational water use, we considered a value of $1000 \mathrm{~m}^{3}$ per year as a proxy, as recommended by the experts in the field at the Building and Technology Department of Graz University of Technology. Finally, the endof-life of the building, covering transportation of materials to recycling sites, waste processing, and disposal (modules C2 to C4), is modeled based on the Belgian OVAM Report Environmental Profile of Building Elements (OVAM 2018). The Belgian report was considered as the most robust document providing representative data which is also valid for the Austrian context. The report states that with the exception of soil, all construction and demolition waste, whether sorted on-site or not, is transported from the construction/demolition site to a sorting facility/collection point (e.g., metal dealer or crusher), and from there, it is eventually further dispatched to recycling, reuse, incineration, energy recovery, or landfill (OVAM 2018). The relative share of materials that is either landfilled, incinerated, reused, or recycled is given for each distinct material category, which then also results in specific transport distances for each material. All the materials listed in our bill of quantities were classified in the categories defined by the report, in order to obtain specific 
transportation distances and shares of materials directed to each end-of-life activity.

Our inventory relied on background data from the ecoinvent database v.3.5. We used European average data but adapted it - whenever possible- to fit with Austrian specificities. As for the treatment of multifunctionality, i.e., modeling processes that generate more than one product or have more than one function, we selected the system model: "allocation, recycled content," which is also referred to as the "cut-off approach." All calculations were performed in the LCA software SimaPro v.8. The indicators herein assessed are Global Warming Potential (GWP) and Primary Energy Demand (PED). For the first, we rely on the characterization factors published in the IPCC 2013 report (IPCC 2013), while the second indicator was calculated via the Cumulative Energy Demand method (Frischknecht et al. 2007).

Differences in the environmental performance of buildings can stem from a number of design aspects, such as their energy efficiency, the construction method, or their size and shape (Röck et al. 2020b). The literature has, however, already shown that LCA-related choices can also deeply influence calculated GHG emissions, due to varying system boundary selection, inventory data sources, and life cycle stages (Kellenberger and Althaus 2009; Frischknecht et al. 2020). Studies exclusively covering the macro-components in a building are fairly common, many focusing only on the building's structure and foundation (Lobaccaro et al. 2018; Georges et al. 2015; Wu et al. 2017). In addition, these studies often focus on internal elements (Goggins et al. 2016; Gan et al. 2018; Gaspar and Santos 2015) and certain building services (Cuellar-Franca and Azapagic 2012; Himpe et al. 2013; Lawania and Biswas 2018). This tiered approach to building LCA, lacking potentially relevant building elements, is believed to be due to the complexity of gathering and modeling a detailed bill of quantities, or as a result of the low level of detail in early design stages, when LCA is applied to aid material selection.

To properly assess the differences that arise from following a detailed (described in previous section) or a simplified approach towards building LCA, we modeled the same case study following the simplified calculation method defined in DGNB (2018). The differences mostly apply to the material specification and quantities in the product stage (A1-A3), which has implications for the corresponding alterations in stages A4, B4, C2, C3, and C4, all dependent on the material amounts. Only the following components are included in the simplified approach: (i) external walls (including doors and windows), (ii) roofs, (iii) internal floors and ceilings, (iv) foundations, (v) internal walls, and, finally, (vi) heating, cooling, and ventilation systems (DGNB 2018). However, it should be noted that pipes, ducts, and lines or other systems that are part of the building's technical system are not considered in the simplified approach.

\section{Case study}

The Electronics Based Systems Building (EBS), shown in Fig. 2, is chosen as the case study for the assessment of the environmental impacts. Situated in Graz, Austria, this building was constructed in 2019. As a research facility, the EBS Center intends to group different forms of research in the field of electronics, microelectronics, sensor technology, and computer science and thus promote research cooperation between science and industry. In addition to technology-oriented university spin-offs, start-ups, and small and medium-sized enterprises, industrial companies are to be included as tenants in the field of electronics and microelectronics.

The building provides an energy reference area (ERA)

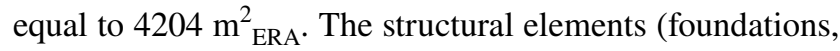
floors, external walls) are constructed in reinforced concrete. Although several types of insulation are used for thermal insulation, polystyrene insulation is utilized as the major material for this purpose. The windows are triple-glazed with wood/aluminum frames. The non-load-bearing walls for the separation of the office areas and the sanitary rooms, as well as various facing shells, are executed in dry construction by means of gypsum plasterboards and metal stud frames. Within the area of the building, the central computer servers of the university are also located. Both the laboratories and server room are supported with cooling and ventilation systems, in addition to the usual HVAC systems in the building. The operational energy demand results in $289 \mathrm{kWh} /$ $\mathrm{m}_{\text {ERA }}^{2} /$ year and consists of heating via heat pump $(22.5 \mathrm{kWh} /$
Fig. 2 EBS Building-Key Facts

\begin{tabular}{|l|l|l|}
\hline & Gross Floor Area (GFA) (Area a - acc. to ÖN B 1800:2013) & $5.412,34 \mathrm{~m}^{2}$ \\
\hline & Net Floor Area (NFA) (Area a - acc. to ÖN B 1800:2013) & $4.560,28 \mathrm{~m}^{2}$ \\
\hline & Energy Reference Area (ERA) & $4.204,20 \mathrm{~m}^{2}$ \\
\cline { 2 - 4 } & Gross Building Volume (Area a - acc. to ÖN B 1800:2013) & $21.671,25 \mathrm{~m}^{3}$ \\
\hline & Energy Consumtion acc. to Element Design & $289 \mathrm{kWh} / \mathrm{m} 2_{\text {ERA }}$ \\
\hline & Energy Consumtion acc. to Energy Certificate & $96,5 \mathrm{kWh} / \mathrm{m} 2_{\text {ERA }}$ \\
\hline
\end{tabular}


$\mathrm{m}_{\text {ERA }}^{2}$ year), heating via district heating $\left(8.8 \mathrm{kWh} / \mathrm{m}^{2}{ }_{\text {ERA }} /\right.$ year), cooling (122 kWh/m ${ }_{\text {ERA }}^{2} /$ year), ventilation $(27.6 \mathrm{kWh} /$ $\mathrm{m}^{2}{ }_{\text {ERA }} /$ year), water (heating, drives, pumps; $3.8 \mathrm{kWh} / \mathrm{m}^{2}{ }_{\mathrm{ERA}} /$ year), other building services (humidification zones and servers, vacuum pump; $2.4 \mathrm{kWh} / \mathrm{m}^{2}$ ERA $/$ year), lighting and electrical devices $\left(48.6 \mathrm{kWh} / \mathrm{m}^{2}\right.$ ERA $/$ year), elevator and emergency services $\left(2.1 \mathrm{kWh} / \mathrm{m}^{2}\right.$ ERA $/$ year $)$, and the server farm $\left(51.2 \mathrm{kWh} / \mathrm{m}^{2}\right.$ ERA $\left./ y e a r\right)$. For the assessment of the environmental impacts of the EBS-building, the functional unit (FU) is defined as energy reference area per year (ERA/year). The quantities of materials employed in the various components of the building, for both simplified and detailed calculation, are presented in Supplementary materials.

\section{Results}

Figure 3 presents simplified and detailed results for global warming potential (GWP) and primary energy (PE) indicators. The overall values of simplified and detailed calculation differ at $29 \%$ and $7.7 \%$, respectively, for GWP and PE. These gaps are sourced from embodied impacts since the simplifications do not influence the building's operational stage. Based on the results, we observe significant gaps equal to $40 \%$ and $44 \%$ between the embodied impacts calculated for GWP and PE indicators with both methods. The electrical equipment implicates the emission of $4 \mathrm{kgCO}_{2} \mathrm{e} / \mathrm{m}^{2}{ }_{\text {ERA }} /$ year and consumption of $63.6 \mathrm{MJ} / \mathrm{m}^{2}{ }_{\text {ERA }} /$ year, presenting the most significant gaps in relative and absolute differences.

Although it has the highest contribution to the overall impacts of the building, electrical equipment is not considered in the simplified study's system boundary. Furthermore, the results highlight two groups of components: those with higher/lower amplitude when calculated with a simplified approach. The first group includes external walls and roofs, while the second group includes the floors, internal walls, and technical equipment. Excluding technical and electrical equipment, the sum of positive and negative discrepancies between the building fabric's environmental impacts is equal to $20 \%$, presenting significant error gaps. Besides, due to these gaps, the contribution of components on the overall impacts of the building changes. These changes influence decision making since they highlight components that are likely not to be the primary factors which need to be focused upon in terms of the reduction of the building's impacts.

Based on preliminary results, we can highlight the necessity to consider the technical and electrical equipment within the system boundary and to improve the simplified approach regarding impact calculation robustness.

To further analyze the importance of values of robustness of environmental impacts for technical and electrical equipment, Fig. 4 compares the values obtained in this study and those found in the literature review published by Röck et al. (2020a, b). For laboratory and research building typology, only Georges et al. (2015) have provided information for the technical and electrical equipment, while other studies have limited the system boundary to the building fabric (Wu et al. 2012; Azari 2014; Kofoworola and Gheewala 2008; Asdrubali et al. 2013; Xie et al. 2018; Wang et al. 2018; Biswas 2014; Azzouz et al. 2017; Attia 2016; Eberhardt et al. 2019). Based on the energy reference area, the KBOB (2016) database also provides simplified information for the impacts of electrical equipment. From the comparison of the results, we observe the significant difference between the detailed analysis provided in this study and the simplified analysis of other studies. Furthermore, the results of technical and electrical equipment are compared with other research analyzing residential building typology. As shown in Fig. 4, the values of impacts for technical equipment provided by Passer et al. (2012), Lobacarro et al. (2018), Ylmén et al. (2019), Kiamili et al. (2020), and Mosteiro-Romero et al. (2014) have almost the same values as those presented in this study. The largest gap is observed with the values presented by Georges et al. (2015), that are 88\% lower than the environmental impacts of technical equipment calculated in this study. The lowest gap equal to $4 \%$ is observed with the values provided by Lobacarro et al. (2018). On the
Fig. 3 Difference between simplified and detailed results

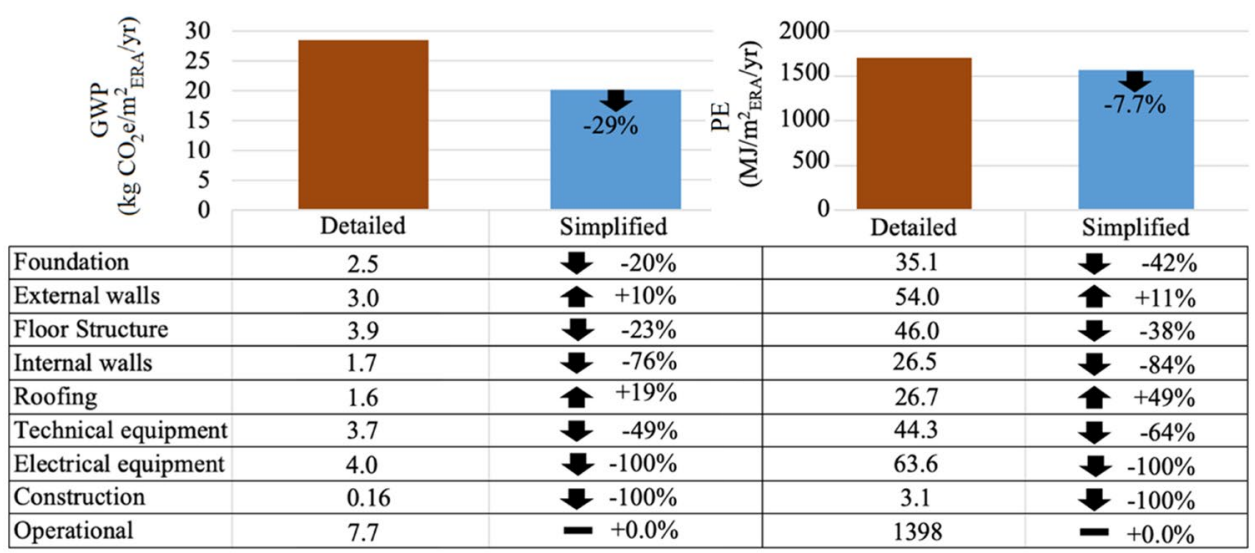


Fig. 4 Comparison of the impacts of this study with previous studies

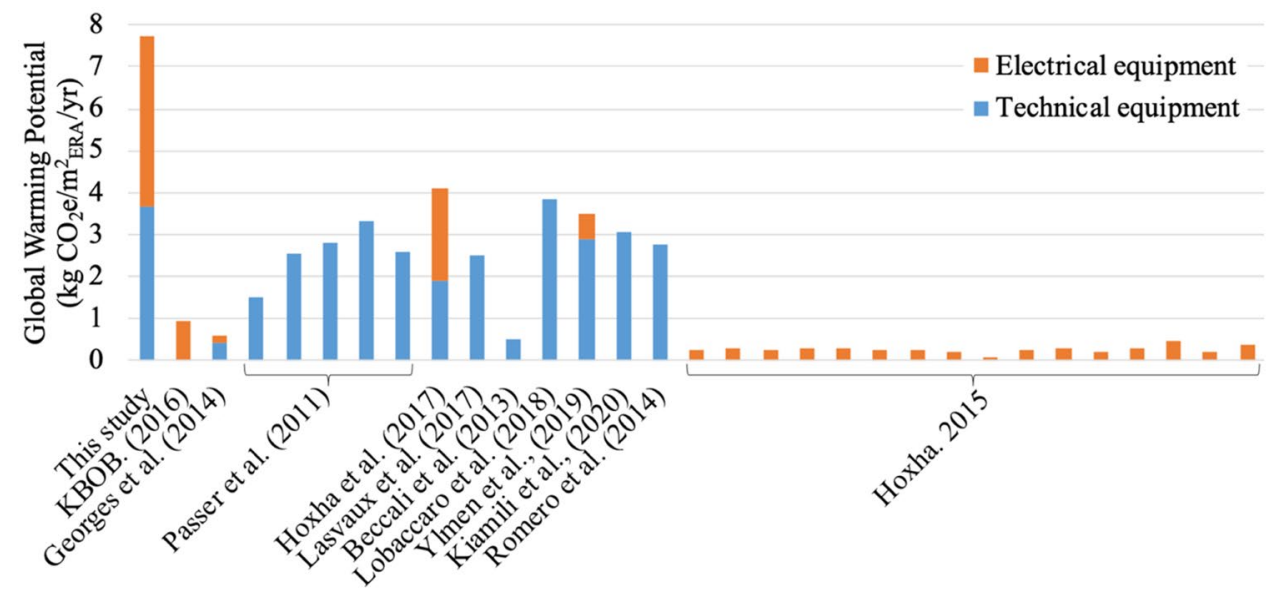

other hand, the impacts of electrical equipment are more critical. This is due to a simplified calculation (Hoxha 2015) of the environmental impacts of electrical equipment and the use of the KBOB database (Hoxha and Jusselme 2017), which, as shown in Fig. 4, carries limitations. These comparisons highlight the gap of the literature to consider the environmental impacts of equipment which, as demonstrated in Figs. 5 and 6, are significant. Other than in the case of Hoxha and Jusselme (2017) when the gap was at the range of 55\%, in all the other cases, the impacts of electrical equipment were not considered within the study's system boundary.

In order to identify the highest levers for the reduction of the environmental impacts of buildings, a detailed analysis and interpretation of its environmental impacts are necessary. Results of the EBS-building for primary energy demand indicator equal to $1698 \mathrm{MJ} / \mathrm{m}^{2}{ }_{\mathrm{ERA}} / \mathrm{year}$ are presented in Fig. 5. The operational stage (B6), equal to $1397 \mathrm{MJ} / \mathrm{m}^{2}$ ERA $/$ year, has the largest contribution. For this stage, cooling is responsible for $43 \%$ followed by appliances with $20 \%$, lighting with $17 \%$, ventilation with $10 \%$, heating with $9 \%$, and hot water with $1 \%$. The high energy demand for cooling and ventilation is due to the server room and laboratories installed in this building. The production stage (A1-A3), equal to $147 \mathrm{MJ} / \mathrm{m}^{2}$ ERA $/$ year, is the second-largest contributor, followed by replacement (B4) equal to $121 \mathrm{MJ} /$ $\mathrm{m}_{\text {ERA }}^{2} /$ year and other stages with lower impacts. Altogether, these stages preset the embodied impacts of the building's materials and components. In the embodied impact (A1-A4 + B4 + C2-C4) equal to $300 \mathrm{MJ} / \mathrm{m}_{\text {ERA }}^{2}$ year, the electrical equipment is the most responsible-for $21.5 \%$. Other components have significant contributions such are the external wall with $18 \%$, technical equipment with $15 \%$, floors with $14 \%$, foundations with $12 \%$, and other components with less than $10 \%$. Due to components with a large lifespan, the production stage of building fabric has higher impacts than the replacement. While for the equipment that has components with a lower lifespan, the replacement stage presents higher impacts than the production. Based on the results obtained, for the minimization of the primary energy demand indicator, the efforts should be focused, first in the
Fig. 5 Results of primary energy demand indicator

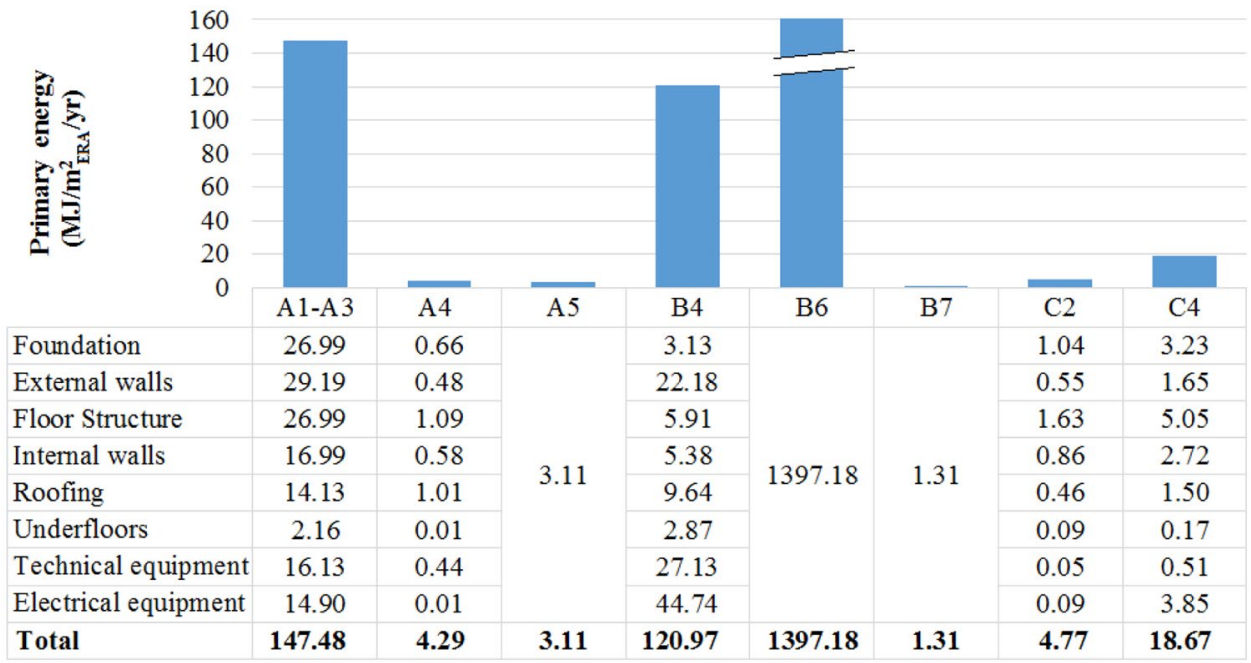


Fig. 6 Results of global warming potential indicator

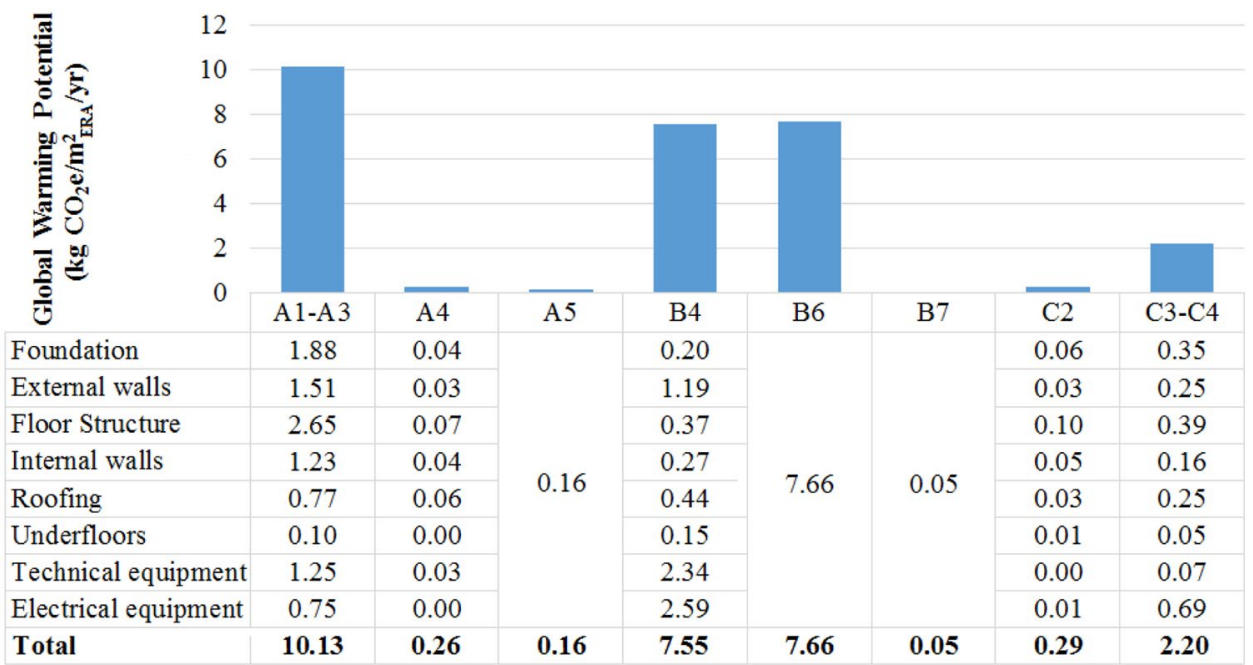

operational stages, and then on the embodied impacts of technical and electrical equipment.

In the case of the global warming potential (GWP) indicator, the results are presented in Fig. 6. The overall impact of the building accounts for $28.3 \mathrm{~kg} \mathrm{CO}_{2} \mathrm{e} / \mathrm{m}^{2}$ ERA $/$ year. The production phase (A1-A3) is found responsible for $36 \%$, the energy demand in the operational stage (B6) for $27 \%$, the replacement of components (B4) for 27\%, and the other stages have a contribution less than $10 \%$. Even for this indicator, the building fabric presents the largest impacts at the production stage but lower values for the replacement. For the production stage, the floors have the largest environmental impacts-equal to $2.65 \mathrm{CO}_{2} \mathrm{e} / \mathrm{m}^{2}{ }_{\text {ERA }}$ /year. The impacts of technical and electrical equipment are also significantequal to $1.25 \mathrm{~kg} \mathrm{CO}_{2} \mathrm{e} / \mathrm{m}^{2}$ ERA $/$ year and $0.75 \mathrm{~kg} \mathrm{CO}_{2} \mathrm{e} / \mathrm{m}^{2}{ }_{\text {ERA }} /$ year, respectively. Due to its short lifespan, the equipment presents high impacts in the use stage, making them the largest contributor to the environmental impacts of the building. According to the building's lifecycle stages, for the reduction of the environmental impact, the efforts should be focused on the production phase. Furthermore, analyses of the environmental impacts of upstream and downstream processes show the embodied impacts (A1-A5 + B4 + C2-C4) responsible for $72 \%$ and the operational (B6-B7) for $28 \%$. Considering the whole embodied impacts during all lifecycle stages, the technical equipment is responsible for $18 \%$ and the electrical equipment for $19.7 \%$, making them a target lever for the reduction of the building's impact. Coupling the results obtained for both indicators, we can conclude that in this laboratory and research building, the technical and electrical equipment is the largest responsible aspect.

For a more detailed analysis, Fig. 7 shows the results of the environmental impacts of all the building's components for the GWP and PE indicators. For the GWP indicator, within the systems of technical equipment, that of cooling presents the largest contribution with more than $47 \%$. The air conditioning system follows with $28 \%$. The heating has a contribution of only $14 \%$, and other systems provide an insignificant contribution. For the electrical equipment, cabling and wiring account for $63 \%$ of the contribution, followed by electrical and electronic systems and lighting.

The results for the PE indicator are very similar. Likewise, for this indicator, the cabling and wiring are the largest contributor with 63\%. Electrical and electronic systems contribute $15 \%$ followed by lighting contributing $12 \%$. With regard the technical equipment, the sanitary and service water system is the largest contributor with $41 \%$. The air conditioning system contributes $27 \%$ and the vacuum system, $11 \%$. Other systems have a lower contribution to the primary energy demand indicator. Based on the results obtained, we can conclude that for the minimization of the environmental impacts of technical equipment, the efforts should be focused on the cooling and air conditioning system, while for the electrical equipment, attention should be given to the cabling and wiring system.

The correlation between the mass of materials employed in the EBS-building and the indicators is shown in Fig. 8. For the results, we observe a general correlation between the primary energy and the global warming potential indicator. However, the quantities of materials employed in the building are not correlated with indicators. Concrete is the material presenting the largest quantity and the highest impacts for the GWP indicator. More than $77 \%$ of the concrete is employed for slabs and external walls and represents around $75 \%$ of the impacts for PE and GWP indicators. On the other hand, the plastic has a lower quantity but presents as the material with higher impacts for the PE indicator and comparable GWP impacts of concrete. Within the plastic material, we considered polyethylene, polymer, polyolefin, PVC, rubber, etc., mainly used in cables and wiring. With a low quantity compared to concrete, steel material used as reinforcement in concrete elements presents significant 

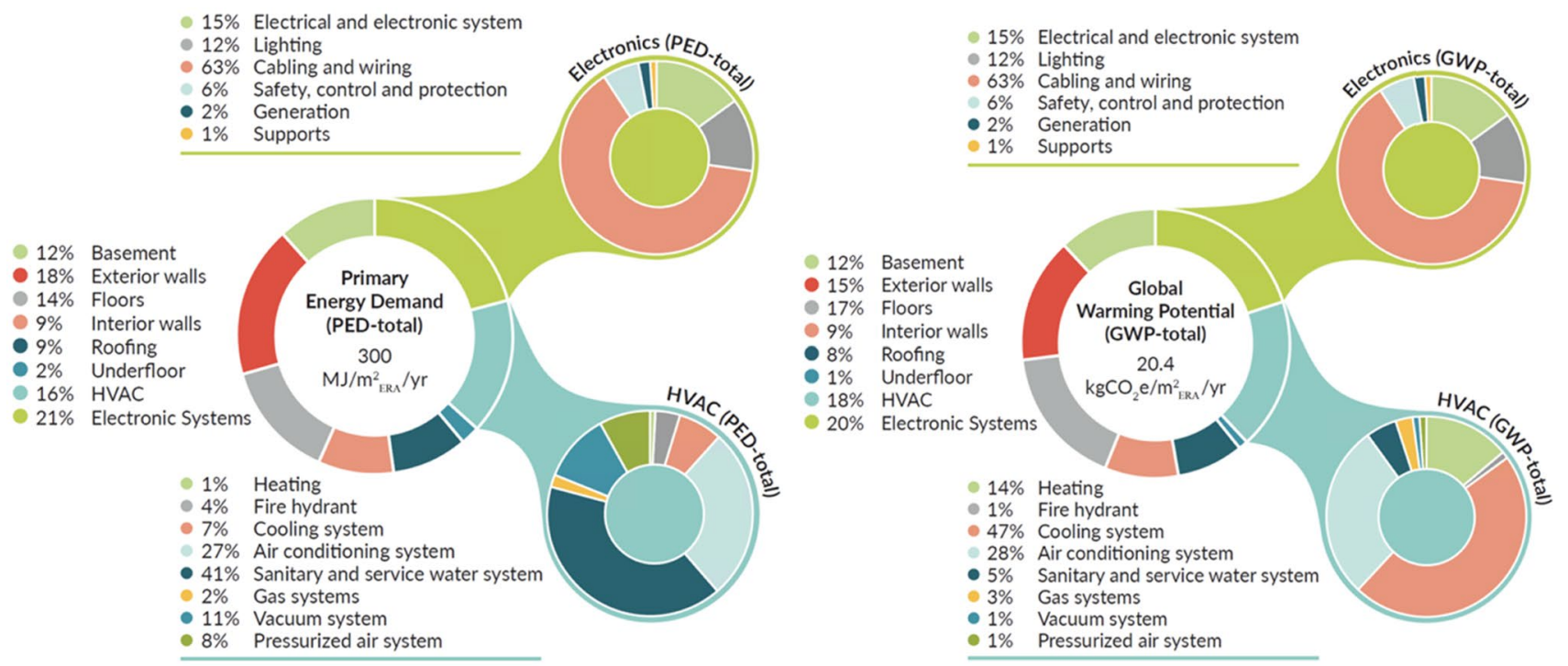

Fig. 7 Contribution of building components for primary energy and global warming indicator

values for both indicators. Within the steel material category, the iron, cast-iron, galvanized steel, etc., which are employed in other building components, are also considered. Furthermore, the types of "steel used in some equipment" also brings a significant contribution to the GWP and PE indicator. For this group of material, various hypotheses are made based on published EPDs (environmental product declaration) to convert equipment such as the pump, airconditioning system, and water heater in the quantity of steel. Aluminum, used mostly in window frames, is another metal with significant impacts. Insulations such as rock wool, glass wool, and polystyrene, even in low mass, have high value for GWP and PE indicators. With lower impacts but high mass contribution, mortar also stands out. On the other hand, glass, wood, bitumen, plaster, brass, and textiles can be considered with low mass with low environmental impacts. In conclusion, to reduce the environmental impacts of the EBS-building, the efforts should be focused on the minimization of the quantity of concrete and mortar employed in this building. Furthermore, plastic, steel, and
Fig. 8 GWP and PE indicator for building materials

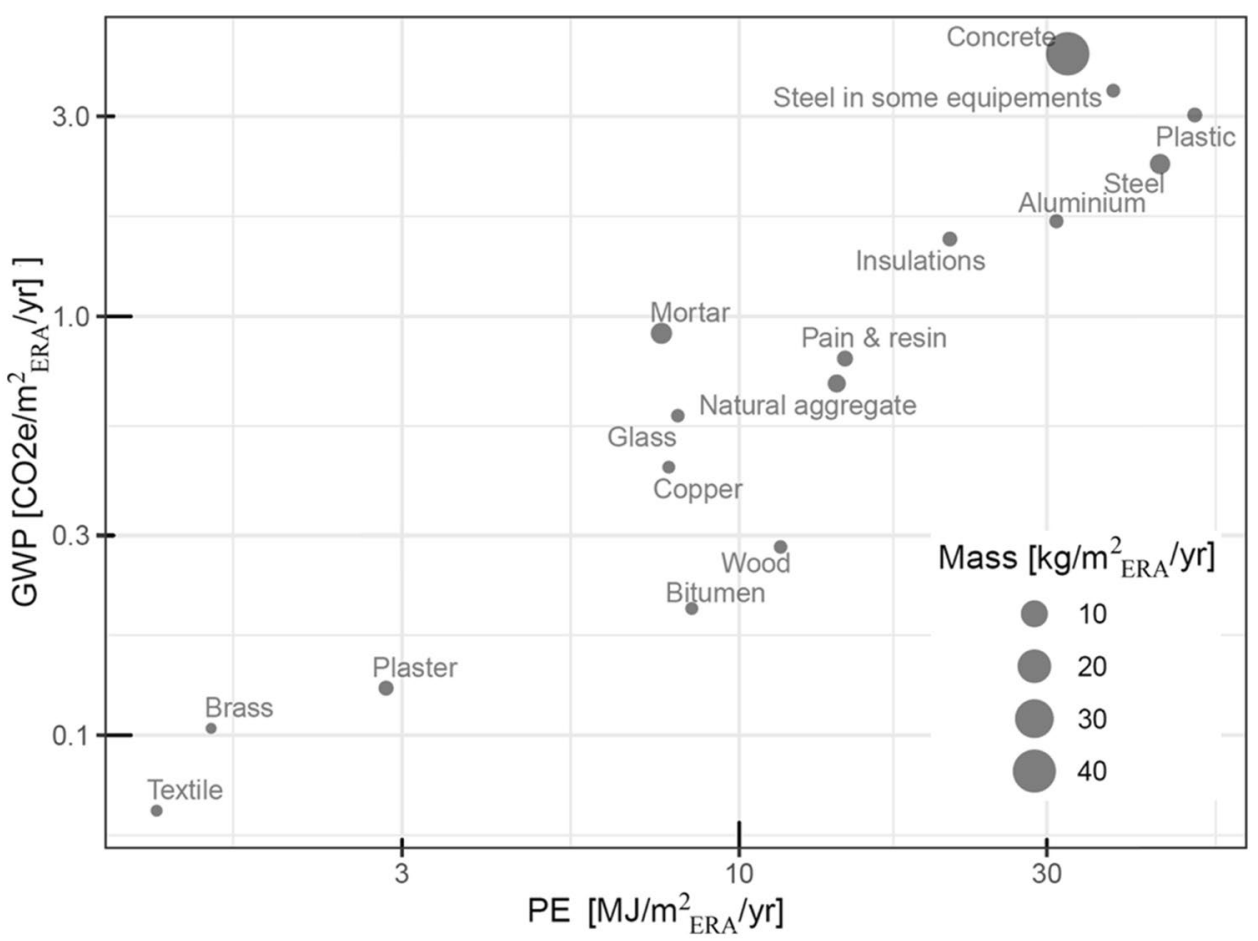


aluminum should be replaced with alternative materials with lower environmental impacts.

\section{Discussion}

Environmental impacts for the laboratory and research building were found to be respectively $1698 \mathrm{MJ} / \mathrm{m}^{2}{ }_{\text {ERA }} /$ year and $28.3 \mathrm{kgCO}_{2} \mathrm{e} / \mathrm{m}^{2}{ }_{E R A} /$ year for primary energy and global warming potential indicators. The operational stage is responsible for $82 \%$ of the PE indicator and $27 \%$ of the GWP. Based on contribution rates, the building can be classified into the new advanced labels (SIA-2040 2017; Hoxha et al. 2016; Röck et al. 2020b). Furthermore, the GWP score of the operational stage is $85 \%$ lower than the current Austrian building stock (Passer et al. 2012; Kreiner et al. 2015). To follow the future strategy for net-zero greenhouse gas emission, the board of the university has decided to buy and use a renewable source of electricity in the laboratory and research building (Maierhofer et al. 2020), which explains the low impacts of the operational stage. However, as a result of high embodied impacts, this building does not reach the 2050 targets set for sustainable use of resources and prevention of climate change (Kellenberger et al. 2012; SIA-2040 2017; Hoxha et al. 2020b). Several reasons explain the high embodied impacts of the EBS-building. First, during the design phase, none of the building's actors had the objective to develop a building project with low environmental impacts. Consequently, the building has been constructed with a large amount of concrete for foundations, slabs, and walls. Second, the present study provides a fully detailed assessment of the environmental impacts of the building by considering, in system boundary, more than 87 materials and their derivatives of building fabrics, and technical and electrical equipment. Most previous studies have limited the system boundary to only building fabric, considering around 20 materials (Georges et al. 2015; Lasvaux et al. 2017; Beccali et al. 2013; Mosteiro-Romero et al. 2014; Wang et al. 2018; Biswas 2014; Azzouz et al. 2017; Attia 2016; Eberhardt et al. 2019; Röck et al. 2020b). Lastly, this study assessed the full environmental impacts of technical and electrical equipment. Together they represent $38 \%$ of the embodied impacts, making them a potential lever for minimization of the environmental impacts of building.

Furthermore, this study analyzed the discrepancies between the results calculated with a simplified and detailed approach. Gaps between results calculated with both approaches equal to $29 \%$ and $7.7 \%$ were found for the GWP and PE indicators. These differences were from the embodied impacts and most specifically from the electrical and technical equipment excluded from the study's system boundary. The comparisons of the environmental impacts of technical and electrical equipment evaluated in this study with those of other studies (KBOB 2016; Georges et al. 2015; Passer et al. 2012; Hoxha and Jusselme 2017; Lasvaux et al. 2017; Beccali et al. 2013; Lobaccaro et al. 2018; Mosteiro-Romero et al. 2014; Hoxha 2015) show differences of a range of 5-95\%. Several reasons such as building typology, life cycle inventory database, system boundary, and hypotheses considered in calculations are associated to result discrepancies between different studies (Röck et al. 2020b; Frischknecht et al. 2020). Since the results of technical and electrical equipment are compared for university and office cases on the basis of the same functional unit, the source of differences, according to Peuportier (2001), cannot be related to building typology. Regarding the life cycle inventory database, a more detailed analysis shows that most of the studies (Georges et al. 2015; Passer et al. 2012; Beccali et al. 2013; Lobaccaro et al. 2018; Mosteiro-Romero et al. 2014) used the ecoinvent database for the calculation of the environmental impacts of electrical and technical equipment. One study (Hoxha and Jusselme 2017) used the KBOB database that largely relies on the ecoinvent database (Frischknecht et al. 2013) and the last group (Hoxha 2015; Lasvaux et al. 2017) used the French database (INIES 2009). For the studies using ecoinvent, we can confirm that the gaps are not influences from the database, whereas the differences with the studies using the French database are mainly related to the limitation of system boundary for calculating the environmental impacts of all technical and electrical equipment. Based on this evidence, we can state that the comparison of the environmental impacts of technical and electrical equipment evaluated in this study with those presented in other studies can be considered robust. These differences are mainly from hypotheses considered during the assessment of impacts and the limitation of system boundaries that are both associated with the simplification feature.

Finally, as in typical building LCA practice, it was a cumbersome task to find technologically and geographically representative unit process datasets to represent each material in the assessed case study building. In fact, as is the case for many other countries, no consolidated Austrian life cycle inventory database exists. While there are some national Environmental Product Declarations (EPD) available, the transparency of the inventory and the possibility to adapt certain inputs and outputs within a unit process to increase representativeness was key for our modeling. Still, whenever an ideal fit could not be identified, we chose the best available proxy according to our knowledge of Austrian production practices. Moreover, a deeper analysis shows discrepancies of the range of $45 \%$ between the simplified and detailed results of embodied impacts. Around 50\% of differences were due to structural elements, similar to the result found by Kellenberger and Althaus (2009), and 50\% due to technical and electrical equipment. On the other hand, a detailed calculation of embodied impacts and the integration of the environmental impacts of technical and electrical equipment 
are possible only in a detailed design phase. To overcome this gap, we recommend considering an error of $20 \%$ for the environmental impacts of structural elements calculated with a simplified method. Concerning technical equipment, several papers have provided information for the environmental impacts. Since the discrepancies with our results were of a lower degree, we recommend a ratio of $3.7 \mathrm{~kg} \mathrm{CO}_{2} \mathrm{e} / \mathrm{m}^{2}{ }_{\text {ERA }} /$ year for a reliable consideration of the impact of technical equipment in the early design phase. While research on electrical equipment was almost completely lacking in the scientific literature, the KBOB database provided information to consider its impact in the early design phase. In this study, we show that the database underestimates the impacts. Based on our result, we recommend a ratio of $4 \mathrm{~kg} \mathrm{CO}_{2} \mathrm{e} /$ $\mathrm{m}^{2}$ ERA $/$ year to consider the environmental impacts of electrical equipment in the early design phase of the building.

\section{Conclusions}

LCAs are known to be data-intensive and dependant on varied methodological choices that influence a study's outcome. When applied to buildings, which are complex and longlived systems, LCAs are faced with a broadened scope of challenges, due to a significant amount of individual components (and their interactions) that must be addressed, and due to different scenarios that must be delineated to consider aspects of its decommissioning and end-of-life. Considering that the choices made today to build or refurbish a building will have long-lasting effects on future carbon reduction strategies, it is imperative that we have increasingly detailed documentation of buildings' environmental impact, to avoid trade-offs and lock-ins that would prevent the society from meeting previously set targets.

Laboratory and research buildings have been sought after to serve as references of environmental performance, often functioning as living labs where low carbon strategies can be portrayed in real-life examples. Their environmental improvement in comparison to business-as-usual design approaches is typically confirmed via LCA, but if over-simplified, results might lead to biased conclusions and even stimulate design practices that fail to fulfill the carbon reduction originally strived for. The mainstream approach of considering solely the building fabric in LCAs, as shown by our results, does not provide a clear picture of the building's environmental performance. Technical and electrical equipment represented almost $38 \%$ of the EBS building's life cycle global warming potential, which confirms that they can significantly contribute to a building's embodied impact. Moreover, the negligence of materials based on their consumed mass can also mislead conclusions, which highlights the significant contribution of materials such as plastic, used in far lower quantities than concrete. Again, most of the plastic assessed is used in cables and wiring, typically neglected in most building LCAs. This proves the argument that a building's environmental impact cannot be simplistically interpreted as the sum of the environmental impacts of its major components. For our specific case study, if a more simplified list of materials and components had grounded the results, the identification of hotspots and deriving recommendations to lower the building's impact would have diverged significantly. If we aim for a truly low-impact building stock, we must ground our design proposals on highly detailed LCA studies, covering a comprehensive bill of materials and (almost) all life cycle stages.

Supplementary information The online version contains supplementary material available at https://doi.org/10.1007/s11367-021-01919-9.

Acknowledgments The analysis and results described in this paper relate to ongoing research within the international project IEA EBC Annex 72 and ParisBuildings, which are financially supported by the Austrian Federal Ministry of Climate Action, Environment, Energy, Mobility, Innovation and Technology (BMK) via the Austrian Research Promotion Agency (FFG) Grant \#864142 and the Klima- und Energiefonds, ACRP11 KR18AC0K14693, as well as by Graz University of Technology who provided the building data and support. The authors thank Anatole Truong Nhu for helping with the data collection and calculation and Nora Hoti for providing help with data illustration. We thank the anonymous reviewers for their careful reading of our manuscript and their many insightful comments and suggestions.

Funding Open access funding provided by Graz University of Technology.

Open Access This article is licensed under a Creative Commons Attribution 4.0 International License, which permits use, sharing, adaptation, distribution and reproduction in any medium or format, as long as you give appropriate credit to the original author(s) and the source, provide a link to the Creative Commons licence, and indicate if changes were made. The images or other third party material in this article are included in the article's Creative Commons licence, unless indicated otherwise in a credit line to the material. If material is not included in the article's Creative Commons licence and your intended use is not permitted by statutory regulation or exceeds the permitted use, you will need to obtain permission directly from the copyright holder. To view a copy of this licence, visit http://creativecommons.org/licenses/by/4.0/.

\section{References}

Allianz Nachhaltige Universitäten in Österreich - AG Nachhaltiges Bauen (2020) Positionspapier zur Errichtung von nachhaltigen Universitätsgebäuden. http://nachhaltigeuniversitaeten.at/wp-content/uploads/2020/ 03/2020-01-23_Positionspapier_Nachhaltiges_Bauen.pdf

Asdrubali F, Baldassarri C, Fthenakis V (2013) Life cycle analysis in the construction sector: guiding the optimization of conventional Italian buildings. Energ Buildings 64:73-89

Attia S (2016) Towards regenerative and positive impact architecture: A comparison of two net zero energy buildings. Sustain Urban Areas 26:393-406

Azari R (2014) Integrated energy and environmental life cycle assessment of office building envelopes. Energ Buildings 82:156-162 
Azzouz A, Borchers M, Moreira J, Mavrogianni A (2017) Life cycle assessment of energy conservation measures during early stage office building design: a case study in London, UK. Energ Buildings 139:547-568

Beccali M, Cellura M, Fontana M, Longo S, Mistretta M (2013) Energy retrofit of a single-family house: life cycle net energy saving and environmental benefits. Renew Sustain Energy Rev 27:283-293

Biswas WK (2014) Carbon footprint and embodied energy consumption assessment of building construction works in Western Australia. Int J Sustain Built Environ 3(2):179-186

Blengini GA (2009) Life cycle of buildings, demolition and recycling potential: a case study in Turin, Italy. Build Environ 44:319-330. https://doi.org/10.1016/j.buildenv.2008.03.007

Blengini GA, Di Carlo T (2010) The changing role of life cycle phases, subsystems and materials in the LCA of low energy buildings. Energ Buildings 42:869-880. https://doi.org/10.1016/j.enbuild. 2009.12.009

BNB Nutzungsdauern von Bauteilen (2017) https://www. nachhaltigesbauen.de/austausch/nutzungsdauern-von-bauteilen/. accessed on the 10.02.2021

Buyle M, Braet J, Audenaert A (2013) Life cycle assessment in the construction sector: a review. Renew Sustain Energy Rev 26:379-388. https://doi.org/10.1016/j.rser.2013.05.001

CCCA (2020) Graz declaration for climate protection in the built environment. https://gd.ccca.ac.at. accessed at the 29.10.2020

Chang CC, Shi W, Mehta P, Dauwels J (2019) Life cycle energy assessment of university buildings in tropical climate. J Clean Prod 239:117930

Cuéllar-Franca RM, Azapagic A (2012) Environmental impacts of the UK residential sector: life cycle assessment of houses. Build Environ 54:86-99. https://doi.org/10.1016/j.buildenv.2012.02.005

DGNB (2018) DGBB system: criteria set new construction building. German Sustainable Building Council. Stuttgart, Germany. https://static.dgnb.de/fileadmin/dgnb-system/downloads/criteria/ DGNB-System-2018-EN.pdf

EN-15978 (2011) Sustainability of construction works-assessment of environmental performance of buildings - calculation method. European Committee for Standardization (CEN)

Eberhardt LCM, Birgisdóttir H, Birkved M (2019) Life cycle assessment of a Danish office building designed for disassembly. Build Res Inf 47(6):666-680

Echarri-Iribarren V, Echarri-Iribarren F, Rizo-Maestre C (2019) Ceramic panels versus aluminium in buildings: Energy consumption and environmental impact assessment with a new methodology. Appl Energy 959-974. https://doi.org/10.1016/j. apenergy.2018.08.091

Frischknecht R, Friedli R, Gugerli H (2013) The Swiss platform of life cycle assessment data in the building sector-connecting industry, administration, builders and research. The 6th International Conference on Life Cycle Management in Gothenburg

Frischknecht R, Jungbluth N, Althaus HJ, Doka G, Dones R, Hischier R, Hellweg S, Humbert S, Margni M, Nemecek T, Spielmann M (2007) Implementation of life cycle impact assessment methods: data v2.0. Ecoinvent Report No. 3. Dübendorf, Switzerland: Swiss Centre for Life Cycle Inventories

Frischknecht R, Ramseier L, Yang W, Birgisdottir H, Chae CU, Lützkendorf T, Zara O (2020) Comparison of the greenhouse gas emissions of a high-rise residential building assessed with different national LCA approaches-IEA EBC Annex 72. In IOP Conference Series. Earth Environ Sci 588(2):022029. IOP Publishing

Gan VJL, Deng M, Tse KT, Chan CM, Lo IMC, Cheng JCP (2018) Holistic BIM framework for sustainable low carbon design of high-rise buildings. J Clean Prod 195:1091-1104. https://doi.org/ 10.1016/j.jclepro.2018.05.272
Gaspar PL, Santos AL (2015) Embodied energy on refurbishment vs. demolition: a southern Europe case study. Energy Build 87:386-394. https://doi.org/10.1016/j.enbuild.2014.11.040

Georges L, Haase M, Houlihan Wiberg A, Kristjansdottir T, Risholt B (2015) Life cycle emissions analysis of two nZEB concepts. Build Res Inf 43(1):82-93

Goggins J, Moran P, Armstrong A, Hajdukiewicz M (2016) Lifecycle environmental and economic performance of nearly zero energy buildings (NZEB) in Ireland. Energy Build 116:622-637. https:// doi.org/10.1016/j.enbuild.2016.01.016

Habert G, Röck M, Steininger K, Lupísek A, Birgisdottir H, Desing H, Chandrakumar C, Pittau F, Passer A, Rovers R, Slavkovic K, Hollberg A, Hoxha E, Jusselme T, Nault E, Allacker K, Lützkendorf T (2020) Carbon budgets for buildings: harmonising temporal, spatial and sectoral dimensions. Buildings and Cities 1:429-452. https://doi. org/10.5334/bc.47

Häfliger IF, John V, Passer A, Lasvaux S, Hoxha E, Saade MRM, Habert G (2017) Buildings environmental impacts' sensitivity related to LCA modelling choices of construction materials. J Clean Prod 156. https://doi.org/10.1016/j.jclepro.2017.04.052

Häkkinen T, Kuittinen M, Ruuska A, Jung N (2015) Reducing embodied carbon during the design process of buildings. Journal of Building Engineering 4:1-13. https://doi.org/10.1016/j.jobe. 2015.06.005

Himpe E, Trappers L, Debacker W, Delghust M, Laverge J, Janssens A, Moens J, Van Holm M (2013) Life cycle energy analysis of a zero-energy house. Build Res Inf 41:435-449. https://doi.org/10. 1080/09613218.2013.777329

Hoxha E (2015) Amélioration de la fiabilité des évaluations environnementales des bâtiments (Doctoral dissertation, Paris Est)

Hoxha E, Jusselme T (2017) On the necessity of improving the environmental impacts of furniture and appliances in net-zero energy buildings

Hoxha E, Jusselme T, Brambilla A, Cozza S, Andersen M, Rey E (2016) Impact targets as guidelines towards low carbon buildings: preliminary concept. In PLEA (No. CONF)

Hoxha E, Liardet C, Jusselme T (2020a) Office densification effects on comfort, energy, and carbon lifecycle performance: an integrated and exploratory study. Sustain Urban Areas 55:102032

Hoxha E, Röck M, Truger B, Steininger K, Passer A (2020b) Austrian GHG emission targets for new buildings and major renovations: an exploratory study. World Sustainable Built Environment Online Conference. Sweden

INIES (2009) National French Database. http://www.inies.fr/

IPCC (2013) Climate Change 2013: The physical science basis. Contribution of Working Group I to the Fifth Assessment Report of the Intergovernmental Panel on Climate Change [Stocker TF, Qin D, Plattner G-K, Tignor M, Allen SK, Boschung J, Nauels A, Xia Y, Bex V, Midgley PM (eds.)]. Cambridge University Press, Cambridge, United Kingdom and New York, NY, USA, 1535 pp

IPCC (2018) Summary for policymakers. In: Global warming of $1.5^{\circ} \mathrm{C}$. An IPCC Special Report on the impacts of global warming of $1.5^{\circ} \mathrm{C}$ above pre-industrial levels and related global greenhouse gas emission pathways, in the context of strengthening the global response to the threat of climate change, sustainable development, and efforts to eradicate poverty [Masson-Delmotte V, Zhai P, Pörtner H-O, Roberts D, Skea J, Shukla PR, Pirani A, Moufouma-Okia W, Péan C, Pidcock R, Connors S, Matthews JBR, Chen Y, Zhou X, Gomis MI, Lonnoy E, Maycock T, Tignor M, Waterfield T (eds.)]. In Press

KBOB (2016) Koordinationskonferenz der Bau- und Liegenschaftsorgane der öffentlichen Bauherren (KBOB). Empfehlung Ökobilanzdaten im Baubereich 2009/1:2016. https://www.kbob.admin.ch/kbob/de/ home/themen-leistungen/nachhaltiges-bauen/oekobilanzdaten baubereich.html. (Accessed 10 October 2020) 
Kellenberger D, Ménard M, Schneider S, Org M, Victor K, Lenel S (2012) Réhabiliter des friches industrielles pour réaliser la société à 2000 watts. Guide et exemples, Projet conjoint de Stadt Zürich, Zürich ewz, Confédératioin Suisse, Switzerland

Kellenberger D, Althaus HJ (2009) Relevance of simplifications in LCA of building components. Build Environ 44(4):818-825

Kiamili C, Hollberg A, Habert G (2020) Detailed Assessment of Embodied Carbon of HVAC Systemsfor a New Office Building Based on BIM. Sustainability 12(8):3372

Kofoworola OF, Gheewala SH (2008) Environmental life cycle assessment of a commercial office building in Thailand. Int J Life Cycle Assess 13(6):498

Kreiner H, Passer A, Wallbaum H (2015) A new systemic approach to improve the sustainability performance of office buildings in the early design stage. Energ Buildings 109:385-396

Kua HW, Wong CL (2012) Analysing the life cycle greenhouse gas emission and energy consumption of a multi-storied commercial building in Singapore from an extended system boundary perspective. Energ Buildings 51:6-14. https://doi.org/10.1016/j.enbuild.2012.03.027

Lasvaux S, Lebert A, Achim F, Grannec F, Hoxha E, Nibel S, Schiopu N, Chevalier J (2017) Towards guidance values for the environmental performance of buildings: application to the statistical analysis of 40 low-energy single family houses' LCA in France. Int J Life Cycle Assess 22(5):657-674

Lawania K, Biswas WK (2018) Application of life cycle assessment approach to deliver low carbon houses at regional level in Western Australia. Int J Life Cycle Assess 23:204-224. https://doi.org/10. 1007/s11367-017-1314-y

Lobaccaro G, Wiberg AH, Ceci G, Manni M, Lolli N, Berardi U (2018) Parametric design to minimize the embodied GHG emissions in a ZEB. Energ Buildings 167:106-123

Maierhofer D, Hoxha E, Passer A (2020) Life cycle assessment of the electronics-based systems building at the Graz University of Technology (in German). BauSIM 2020 September 23-25, Online Conference. Austria

Mosteiro-Romero M, Krogmann U, Wallbaum H, Ostermeyer Y, Senick JS, Andrews CJ (2014) Relative importance of electricity sources and construction practices in residential buildings: a Swiss-US comparison of energy related life-cycle impacts. Energ Buildings 68:620-631

OVAM (2018) Environmental profile of building elements [update 2017]. Available at: https://www.vlaanderen.be/publicaties/envir onmental-profile-of-building-elements-update-2017

Pan W, Li K, Teng Y (2018) Rethinking system boundaries of the life cycle carbon emissions of buildings. Renew Sust Energ Rev 90:379-390. https://doi.org/10.1016/j.rser.2018.03.057

Passer A, Kreiner H, Maydl P (2012) Assessment of the environmental performance of buildings: Acritical evaluation of the influence of technical building equipment on residential buildings. Int J Life Cycle Assess 17(9):1116-1130. https://doi.org/10.1007/ s11367-012-0435-6

Passer A, Ouellet-Plamondon C, Kenneally P, John V, Habert G (2016) The impact of future scenarios on building refurbishment strategies towards plus energy buildings. Energ Buildings 124:153-163. https://doi.org/10.1016/j.enbuild.2016.04.008

Peuportier BLP (2001) Life cycle assessment applied to the comparative evaluation of single family houses in the French context. Energ Buildings 33(5):443-450

Pomponi F, Moncaster A (2016) Embodied carbon mitigation and reduction in the built environment - what does the evidence say? J Environ Manage 181:687-700. https://doi.org/10.1016/j.jenvman.2016.08.036

Rasmussen FN, Ganassali S, Zimmermann RK, Lavagna M, Campioli A, Birgisdóttir H (2019) LCA benchmarks for residential buildings in Northern Italy and Denmark-learnings from comparing two different contexts. Build Res Inf 47:833-849. https://doi.org/ 10.1080/09613218.2019.1613883
Röck M, Balouktsi M, Saade MRM, Rasmussen FN, Hoxha E, Birgisdottir H, Frischknecht R, Habert G, Passer A, Lützkendorf T (2020a) Embodied GHG emissions of buildings - Critical reflection of benchmark comparison and in-depth analysis of drivers. IOP Conf Ser Earth Environ Sci 588. https://doi.org/10.1088/17551315/588/3/032048

Röck M, Saade MRM, Balouktsi M, Rasmussen FN, Birgisdottir H, Frischknecht R, Habert G, Lützkendorf T, Passer A (2020b) Embodied GHG emissions of buildings - The hidden challenge for effective climate change mitigation. Appl Energy 258:114107. https://doi.org/10.1016/j.apenergy.2019.114107

Säynäjoki A, Heinonen J, Junnila S (2012) A scenario analysis of the life cycle greenhouse gas emissions of a new residential area. Environ Res Lett 7:34037. https://doi.org/10.1088/1748-9326/7/3/034037

Scheuer C, Keoleian GA, Reppe P (2003) Life cycle energy and environmental performance of a new university building: modeling challenges and design implications. Energ Buildings 35(10):1049-1064

SIA-2040 (2017) The SIA path to energy efficiency (in French). Swiss society of engineers and architects. Zürich, Switzerland

Sinha R, Lennartsson M, Frostell B (2016) Environmental footprint assessment of building structures: a comparative study. Build Environ 104:162-171. https://doi.org/10.1016/j.buildenv.2016.05.012

Spirinckx C et al (2018) PEF4Buildings - Study on the Application of the PEF Method and related guidance documents to a newly office building (ENV.B.1/ETU/2016/0052LV) - Deliverable D3: Report on PEF study of newly built office building. Tech. rep. 07. Publications Office of the European Union p. 428

Stephan A, Crawford RH, de Myttenaere K (2013) A comprehensive assessment of the life cycle energy demand of passive houses. Appl Energy 112:23-34. https://doi.org/10.1016/j.apenergy.2013.05.076

Varun Sharma A, Shree V, Nautiyal H (2012) Life cycle environmental assessment of an educational building in Northern India: a case study. Sustain Urban Areas 4:22-28. https://doi.org/10.1016/j.scs. 2012.03.002

VDI2067 (2008) Blatt 1: Wirtschaftlichkeitgebäudetechnischer Anlagen - Grund-lagen und Kostenberechnung. Tech Rep

Vuarnoz D, Hoxha E, Nembrini J, Jusselme T, Cozza S (2020) Assessing the gap between a normative and a reality-based model of building LCA. Journal of Building Engineering 31:101454

Wang J, Yu C, Pan W (2018) Life cycle energy of high-rise office buildings in Hong Kong. Energ Buildings 167:152-164

Wu HJ, Yuan ZW, Zhang L, Bi J (2012) Life cycle energy consumption and $\mathrm{CO} 2$ emission of an office building in China. Int J Life Cycle Assess 17(2):105-118

Wu X, Peng B, Lin B (2017) A dynamic life cycle carbon emission assessment on green and non-green buildings in China. Energ Buildings 149:272-281. https://doi.org/10.1016/j.enbuild.2017.05.041

Xie H, Gong G, Fu M, Wang P, Li L (2018) A thermodynamic method to calculate energy \& exergy consumption and $\mathrm{CO} 2$ emission of building materials based on economic indicator. In Building Simulation 11(2):235-244. Tsinghua University Press

Xue Z, Liu H, Zhang Q, Wang J, Fan J, Zhou X (2020) The impact assessment of campus buildings based on a life cycle assessmentlife cycle cost integrated model. Sustainability 12:294. https://doi. org/10.3390/su12010294

Ylmén P, Peñaloza D, Mjörnell K (2019) Life cycle assessment of an office building based on site-specific data. Energies 12(13):2588

Zhang X, Zheng R, Wang F (2019) Uncertainty in the life cycle assessment of building emissions: a comparative case study of stochastic approaches. Build Environ 147:121-131. https://doi.org/10. 1016/j.buildenv.2018.10.016

Publisher's Note Springer Nature remains neutral with regard to jurisdictional claims in published maps and institutional affiliations. 